\title{
Pengembangan model pembelajaran tematik Pendidikan jasmani olahraga dan kesehatan untuk sekolah dasar
}

\author{
Maharani Fatima Gandasari \\ STKIP Pamane Talino, Desa Raja, Ngabang, Kabupaten Landak, Kalimantan Barat 79357 \\ Corresponding Author. Email: Maharani.fg8@gmail.com
}

\begin{abstract}
Abstrak
Penelitian ini bertujuan untuk (1). Menghasilkan model pengembangan pembelajaran tematik materi penjasorkes yang disajikan sesuai dengan tema pembelajaran kelas II SD, (2) Menguji keterlaksanaan model pengembangan pembelajaran tematik materi penjasorkes yang disajikan sesuai dengan tema pembelajaran kelas II sekolah dasar, (3) Menguji ketertarikan peserta didik terhadap model pengembangan pembelajaran tematik materi penjasorkes yang disajikan sesuai dengan tema pembelajaran kelas II sekolah dasar. Metode yang digunakan dalam penelitian ini adalah Research and Development yakni pengembangan produk berupa model pembelajaran tematik. Teknik pengumpulan data menggunakan pedoman observasi dan kuisioner dengan teknik analisis data menggunakan statistik deskriptif kemudian di konversikan ke data kualitatif. Subjek penelitian adalah siswa kelas II di 22 sekolah dasar di Kota Salatiga. Hasil secara keseluruhan dari uji skala terbatas dan uji skala luas dari ketertarikan produk dari peserta didik rata-rata 85,59 (Baik), keterterimaan produk dari guru rata-rata 85,55 (Baik), keterlaksanaan dari penilaian kognitif rata-rata 82,63 (Baik), afektif rata-rata 83,06 (Baik) dan psikomotor rata-rata 82,75 (Baik). Keterterimaan produk yang dihasilkan diperoleh nilai rata-rata 85,57 (Baik) dan keterlaksanaan nilai rata-rata 82,81 (Baik). Kesimpulan yang diperoleh dalam penelitian ini yaitubahwa model pembelajaran materi penjasorkes untuk kelas II sekolah dasar yang dikembangkan dapat diterima dengan Baik dan dapat terlaksana dengan Baik. Disarankan bagi guru Penjasorkes untuk dapat menggunakan model pembelajaran tematik yang dihasilkan sebagai gambaran dan acuan guru penjasorkes untuk mengembangkan materi pembelajaran yang lebih variatif dan inovatif.
\end{abstract}

Kata Kunci: pengembangan, pembelajaran tematik, penjasorkes.

\section{The development of thematic learning model for penjasorkes materials of the primary school}

\begin{abstract}
The research investigated to (1) produce the development of thematic learning model of Penjasorkes material which was presented by the learning theme of the $2^{\text {nd }}$ grade in primary school. (2) It also investigated to test the implementation of thematic learning model of Penjasorkes material which was presented by the learning theme of the $2^{\text {nd }}$ grade in primary school. (3) And then, it investigated to test the interest of learners to thematic learning model of Penjasorkes material which was presented by the learning theme of the $2^{\text {nd }}$ grade in primary school. The Method that is used in this research is research and development that is a development product as thematic learning. Techniques of collecting data used observation and questionnaire in which analyze techniques data used statistical descriptions than converted into qualitative data. Research subjects are students of $2^{\text {nd }}$-grade primary school in 22 primary school in Salatiga. Overall results of tests on a limited scale and large-scale test of interest in the product of the average learner 85,59 (B), Acceptability of products produced average values obtained $85,57(B)$ and the enforceability of the average value of $82,81(B)$. The conclusion of the study was the thematic learning model of Penjasorkes materials for the $2^{\text {nd }}$ grade of primary school, which was developed, could be very good acceptable and could be accomplished well. For the teachers of Penjasorkes hopefully could use the product of thematic learning materials of Penjasorkes as an overview and reference to develop learning materials more creative and innovative.
\end{abstract}

Keywords: Development, Thematic learning, Penjasorkes. 


\section{Jurnal Pendidikan Jasmani Indonesia, 15 (1), 2019 - 23}

Maharani Fatima Gandasari

\section{PENDAHULUAN}

Pendidikan jasmani olahraga dan kesehatan (penjasorkes) merupakan bagian penting dari kurikulum menurut Rustiana (2013, p. 34) sehingga ada beberapa alasan penjasorkes perlu mendapat penekanan di sekolah dasar yaitu: (1) bermain merupakan dunia anak, (2) pendidikan jasmani berhubungan dengan kesehatan anak, (3) pendidikan jasmani berhubungan dengan prestasi pelajaran lain di sekolah, (4) pendidikan jasmani berhubungan dengan perkembangan sosial. Dalam pelaksanaan pendidikan jasmani seperti mata pelajaran lainnya keempat faktor tidak bolah dilupakan yaitu: tujuan, materi, metode dan evaluasi. "salah satu prinsip pentingnya pendidikan jasmani adalah partisipasi peserta didik secara penuh dan merata" (Husdarta, 2009, p. 163).

Hakekat pembelajaran tematik menurut Trianto $(2010,78)$ dimaknai sebagai pembelajaran yang dirancang berdasarkan tema-tema tertentu. Pembelajaran tematik merupakan suatu pendekatan dalam pembelajaran yang secara sengaja mengaitkan beberapa aspek baik dalam intra mata pelajaran maupun antar mata pelajaran. Pembelajaran tematik tidak semata-mata belajar medorong siswa untuk mengetahui (learning to know), tetapi belajar juga untuk melakukan (learning to do), untuk menjadi (learning to be) dan untuk hidup bersama (learning to live together) (Prastowo, 2013, p. 126).

Pembelajaran tematik di sekolah dasar (SD) merupakan suatu hal yang relative baru,sehingga dalam implementasinya belum sebagaimana yang diharapkan. Masih banyak guru yang merasa sulit dalam melaksanakan pembelajaran temati kini. Hal ini terjadi antara lain karena guru belum mendapat pelatihan secara intensif tentang pembelajaran temati kini. Disamping itu juga guru masih sulit meninggalkan kebiasan kegiatan pembelajaran yang penyajiannya berdasarkan mata pelajaran/bidang studi.

Pelaksanaan pembelajaran tematik di sekolah dasar pada saat ini difokuskan pada kelas-kelas bawah (kelas 1 dan 2) atau kelas yang anak-anaknya masih tergolong pada anak usia dini, walaupun sebenarnya pendekatan pembelajaran tematik ini bisa dilakukan di semua kelas sekolah dasar. Oleh karena itu pembelajaran tematik di sekolah dasar sangat perlu untuk diaksanakan dan diterapkan kepada siswa dan pentingnya pemahaman guru tentang pembelajaran tematik di sekolah dasar (Prastowo, 2013, p.90).

Beberapa karakteristik pembelajaran tematik yang menjadi pembeda dengan pembelajaran yang lain adalah sebagaimana berikut: (1) Berpusat pada peserta didik. Maksudnya, pembelajaran berpusat pada siswa, hal ini sesuai dengan pendekatan belajar modern yang menempatkan siswa sebagai subjek belajar, sedangkanposisi guru sebagai fasilitator, (2) Memberikan pengalaman langsung pada peserta didik (direct experiences); dengan pengalaman langsung, siswa dihadapkan pada sesuatu yang nyata sebagai dasar untuk memehami hal-hal yang lebih abstrak, (3) Pemisahan antara mata pelajaran tidak begitu nyata dan jelas maksudnya, fokus pembelajaran diarahkan kepada pembahasan tema-tema yang paling dekat berkaitan dengan kehidupan siswa, (4) Menyajikan suatu konsep dari berbagai mata pelajaran dalam suatu proses pembelajaran. Dengan hal ini siswa diharapkan mampu memahami konsep-konsep tersebut secara utuh serta untuk membantu permasalahan siswadalam kehidupan sehari-hari, (5) Fleksibel atau luwes, artinya bahan ajar dalam satu mata pelajaran dapat dikaitkan dengan mata pelajaran yang lainnya, bahkan dapat dikaitkan dengan lingkungan tempat sekolah dan siswa berada, (6) Hasil pembelajaran sesuai dengan minat dan kebutuhan siswa, sebab siswa diberikan kesempatan untuk mengoptimalkan potensinya sesuai dengan keinginannya, (7) Menggunakan prinsip belajar sambil bermain, sehingga proses pembelajaran terasa lebih menyenangkan (Frasandy, 2017; Suheli, 2018).

Pembelajaran tematik juga memiliki rambu-rambu yang harus diperhatikan yakni tidak semua pelajaran harus dipadukan, kompetensi dasar yang tidak dapat dipadukan, tidak boleh dipaksakan untuk dipadukan, melainkan disajikan secara tersendiri, kompetensi dasar yang tidak tercakup pada tema tertentu harus tetap diajarkan dengan cara melalui tema lain atau secara tersendiri, kegiatan pembelajaran ditekankan pada kemampuan membaca, menulis, berhitung, dan penanaman nilai-nilai moral, tema-tema yang dipilih disesuaikan dengan karakteristik (siswa, lingkungan, dan daerah setempat). 


\section{Jurnal Pendidikan Jasmani Indonesia, 15 (1), 2019 - 24}

Maharani Fatima Gandasari

Adanya permasalahan pada cara guru dalam mengajar penjasorkes tidak ada perubahan bahkan semakin lama semakin menurun. Hal ini dikarenakan metode yang dipilih guru untuk diterapkan ke dalam PBM tidak sesuai, cenderung perhatian siswa lebih berpusat kepada guru sehingga setiap melakukan tugas gerak siswa hanya melakukan berdasarkan perintah guru bukan karena kemauannya sendiri. Siswa cenderung pasif dikarenakan gaya mengajar guru yang monoton dan membosankan sehingga dapat mempengaruhi respond an minat siswa terhadap PBM mata pelajaran penjasorkes.

Konsep yang ada dibenak guru pendidikan jasmani bahwa penjasorkes lebih mengarah kepada kepelatihan atau penguasaan keterampilan cabang olahraga. Harusya pendidikan jasmani lebih menekankan kepada proses dari kemampuan siswa dalam melakukan gerak demi pengembangan kepribadian siswa, bukan hanya sekedar melihat dari hasil suatu gerak, sehingga guru harus menentukan metode pembelajaran yang hendaknya disesuaikan dengan kemampuan dan karakteristik siswa.Siswa kelas dua sekolah dasar yang memiliki karakteristik hampir sama dengan siswa kelas I dimana mereka senang dengan dunia bermain dan kegiatan yang sifatnya gembira.

Pembelajaran tematik merupakan suatu cara dalam menerapkan pembelajaran penjasorkes di sekolah dasar. Pembelajaran tematik meliputi berbagai mata pelajaran yang disajikan secara terpadu dengan tema sebagai pemersatunya. Upaya untuk menyatukan berbagai kompetensi dasar dariberbagai mata pelajaran, perlu adanya kajian yang mendalam dengan mengacu pada standar kompetensi lulusan. Pembelajaran tematik disajikan secara fleksibel, tidak dipaksakan, saling melengkapi, saling terkait, dan tidak terpisahkan. Didalam pelaksanaan pembelajaran tematik guru diharuskan memiliki kompetensi yang mumpuni sesuai dengan bidang keahlian masing-masing dari mata pelajaran yang diajarkan oleh guru tersebut. Guru sekolah dasar hendaknya dapat memahami konsep pembelajaran tematik yang akan dilaksanakan. Pengelolaan pembelajaran tematik (perencanaan, pelaksanaan, dan evaluasi) juga harus diperhatikan oleh guru sekolah dasar (Hidayati, 2016; Samsudin, 2008, p.52).

Kelebihan dari pembelajaran tematik yaitu: (1) Memberikan pengalaman dan kegiatan belajar anak relevan dengan tingkat perkembangannya, (2) Kegiatan yang dipilih sesuai dengan minat dan kebutuhan anak, (3) Kegiatan belajar bermakna bagi anak sehingga hasilnya dapat bertahan lama, (4) Keterampilan berpikir anak berkembang dalam proses pembelajaran terpadu Keterampilan berpikir anak berkembang dalam proses pembelajaran terpadu, (5) Kegiatan belajar mengajar bersifat pragmatis sesuai lingkungan anak, (6) Keterampilan sosial anak berkembang dalam proses pembelajaran terpadu. (Trianto, 2010, p. 88). Dengan demikian pembelajaran tematik cocok untuk diterapkan dalam PBM penjasorkes yang disesuaikan dengan karakteristik dan kemampuan siswa kelas II sekolah dasar. Pendekatan tematik merupakan strategi pembelajaran yang digunakan guru untuk melaksanakan PBM yang sekarang ini sering disebut pembelajaran tematik. Pembelajaran tematik sebenarnya telah lama ada sejak Kurikulum 1994, karena adanya keterbatasan kemampuan dari guru, yakni background pendidikan yang dimiliki guru maupun pelatihan tentang pembelajaran tematik mengakibatkan pembelajaran tematik tidak dapat dilaksanakan dengan baik dan maksimal. Fakta di lapangan guru penjasorkes masih banyak yang yang belum menerapkan dan melaksanakan pembelajaran tematik, hal ini disebabkan karena guru penjasorkes belum paham tentang bagaimana dan apa itu pembelajaran tematik.

Hasil observasi, terdapat 23 dari 43 guru penjasorkes sekolah dasar yang diobservasi belum paham tentang pembelajaran tematik. Data lain menunjukkan 40 dari 43 guru penjasorkes sekolah dasar belum menerapkan pembelajaran tematik. Guru penjasorkes yang sudah menerapkan dan melaksanakan pembelajaran tematik sebanyak 3 guru penjasorkes di sekolah dasar, dua diantaranya merasa kesulitan dalam menerapkan pembelajaran penjasorkes tematik. Kesulitan guru penjasorkes seperti diuraikan sebagai berikut (1) pembuatan RPP dan alat peraga, (2) sarana prasarana, (3) Lingkungan sekitar menekankan ke prestasi anak, (4) penilaian, (5) Sulit membangkitkan respon dan minat anak. Tema yang ada pada siswa kelas II sekolah dasar terdapat delapan tema yang ada (Hidup rukun, Bermain di lingkunganku, Tugas sehari-hari, Aku dan sekolahku, Hidup bersih 


\section{Jurnal Pendidikan Jasmani Indonesia, 15 (1), 2019 - 25}

Maharani Fatima Gandasari

dan sehat, Merawat hewan dan tumbuhan, Air bumi dan matahari, Keselamatan dirumah dan perjalanan) yang dijabarkan lagi ke dalam sub-sub tema. Adapun 3 sekolah dasar yang telah menerapkan pembelajaran tematik dari 43 guru penjasorkes sekolah dasar di Kota Salatiga yang diobservasi, terdapat 2 guru penjasorkes sekolah dasar yang telah menerapkan pembelajaran tematik pada semua tema yang ada, dan ada 1 guru penjasorkes sekolah dasar yang belum menerapkan pembelajaran tematik pada semua tema. Penerapan tema yang sudah dilakukan oleh 3 guru penjasorkes siswa kelas I dan IV.

Sedangkan 40 guru penjasorkes sekolah dasar yang belum menerapkan pembelajaran tematik terdapat 14 guru penjasorkes yang menyatakan belum tahu tentang pembelajaran tematik, 14 guru penjasorkes sekolah dasar belum paham tentang pembelajara tematik dan 12 guru penjasorkes sekolah dasar dengan alasan lain, diantaranya: (1) Belum mendapatkan sosialisasi, (2) Baru beberapa sekolah yang ditunjuk untuk menjadi sampel, (3) Masih menggunakan KTSP, (4) mengikuti kemauan anak, (5) Guru PJOK bukan berlatar belakang penjasorkes. Beberapa fakta yang ada maka perlunya pemahaman yang diberikan kepada para guru penjasorkes tentang pembelajaran tematik, dan diberikan contoh materi pembelajaran tematik yang seperti apa supaya guru penjasorkes lebih mudah memahami, kemungkinan besar guru penjasorkes di sekolah dasar tidak akan dapat menerapkan dan mengimplementasikan pembelajaran tematik. Diharapkan dengan adanya contoh materi pembelajaran tematik penjasorkes dengan jelas, guru penjasorkes akan lebih mudah memahami konsep dari pembelajaran tematik kemudian menerapkan di lapangan dan nantinya guru penjasorkes juga dapat kreatif untuk menciptakan dan menghasilkan model pembelajaran tematik yang lain sesuai dengan inspirasi dan imajinasinya sendiri. Hasil lainnya 43 guru penjasorkes di Kota Salatiga yang menyatakan akan melaksanakan dan menggunakan produk yang dihasilkan nantinya ada 43 guru penjasorkes (100\%).

Adapun tujuan dari pengembangan model pembelajaran tematik mata pelajaran pendidikan jasmani olahraga dan kesehatan (penjasorkes) untuk siswa sekolah dasar kelas II adalah: (1) Menghasilkan contoh model pengembangan pembelajaran tematik materi penjasorkes yang disajikan sesuai dengan tema pembelajaran kelas II sekolah dasar, (2) Menguji keterlaksanaan model pengembangan pembelajaran tematik materi penjasorkes yang disajikan sesuai dengan tema pembelajaran kelas II sekolah dasar, (3) Menguji ketertarikan peserta didik terhadap model pengembangan pembelajaran tematik materi penjasorkes yang disajikan sesuai dengan tema pembelajaran kelas II sekolah dasar.

\section{METODE}

Metode yang digunakan dalam penelitian ini adalah R\&D (Research and Development) yakni pengembangan produk berupa model pembelajaran tematik untuk siswa SD kelas II yang dilakukan dengan tahapan sebagai berikut: (1) analisis kebutuhan produk, (2) mengembangkan produk awal, (3) melakukan validasi ahli, (4) melakukan uji coba skala kecil dan skala besar, (5) revisi produk dan (6) produk akhir. Teknik pengumpulan data menggunakan pedoman observasi dan kuisioner dengan teknik analisis data menggunakan statistik deskriptif kemudian di konversikan ke data kualitatif.

Subjek uji coba adalah sasaran pemakai produk, yaitu siswa sekolah dasar kelas II. Siswa sekolah dasar yang dipilih sebagai subjek uji coba adalah sekolah dasar tertera sebagai berikut:2 Sekolah Dasar kelas II (SD Cebongan 2, SD Ledok 2) untuk uji coba lapangan kelompok kecil, 20 Sekolah Dasar kelas II(Sekolah untuk uji coba lapangan lebih luas)diantaranya SD ledok 04, SD Ledok 05, SD Ledok 07, SD Tegalrejo 04,SD Tegalrejo 02, SD Tegalrejo 05, SD Kumpulrejo 03, SD Kumpulrejo 02, SD Cebongan 3, SD Randuacir 3, SD Mangunsari 05, SD Mangunsari 04, SD Mangunsari 07, SD Kalicacing 02, SD Gendongan 2, SD Gendongan 3, SD Kutowinangun 7, SD Kutowinangun 04, SD Kutowinangun 11, SD Kutowinangun 10.

Jenis data awal yang diperoleh pada penelitian ini adalah data kualitatif dan data kuantitatif yang dikonversi ke data kualitatif. Data kualitatif di dapatkan dari hasil obeservasi dan wawancarasedangkan data kuantitatif diperoleh dari angket/kuesioner. Data tersebut dimaksudkan untuk melihat kualitas dari komponen-komponen pengembangan materi pembelajaran, agar nantinya dapat digunakan dalam proses pembelajaran. 


\section{Jurnal Pendidikan Jasmani Indonesia, 15 (1), 2019 - 26}

Maharani Fatima Gandasari

Instrumen yang dikembangkan dan digunakan dalam penilaian ini meliputi: (1) Kuesioner untuk ahli materi dan guru, (2) Kuesioner untuk siswa dan guru guna mengevaluasi ketertarikan dan keterterimaan produk materi yang dikembangkan.

Data yang diperoleh dianalisis dengan menggunakan statistik deskriptif kualitatif. Analisis ini dimaksudkan untuk menggambarkan karakteristik data pada aspek pembelajaran atau hasil belajar (kognitif, afektif dan psikomotorik). Tujuan yang diharapkan dapat mempermudah memahami data untuk proses analisis selanjutnya. Hasil analisis data digunakan sebagai dasar untuk merevisi produk materi yang dikembangkan. Data kuantitatif yang diperoleh melalui angket penilaian dan wawancara dianalisis dengan menggunakan statistik deskriptif kemudian di konversikan ke data kualitatif.

\section{HASIL DAN PEMBAHASAN}

Hasil yang diperoleh dari uji skala kecil sampai uji skala besar telah dilakukan dimulai dari hasil penilaian validator, hasil yang diperoleh dari uji skala kecil dan uji skala bebas menunjukan bahwa produk yang dikembangkan layak untuk dapat diterapkan dalam pembelajaran penjasorkes tematik kelas II sekolah dasar dan juga produk ini bisa dikembangkan lagi oleh guru penjasorkes. Kesimpulan yang diperoleh dari analisis hasil penelitian seperti pada Tabel 1.

Tabel 1. Rekapitulasi hasil Penelitian

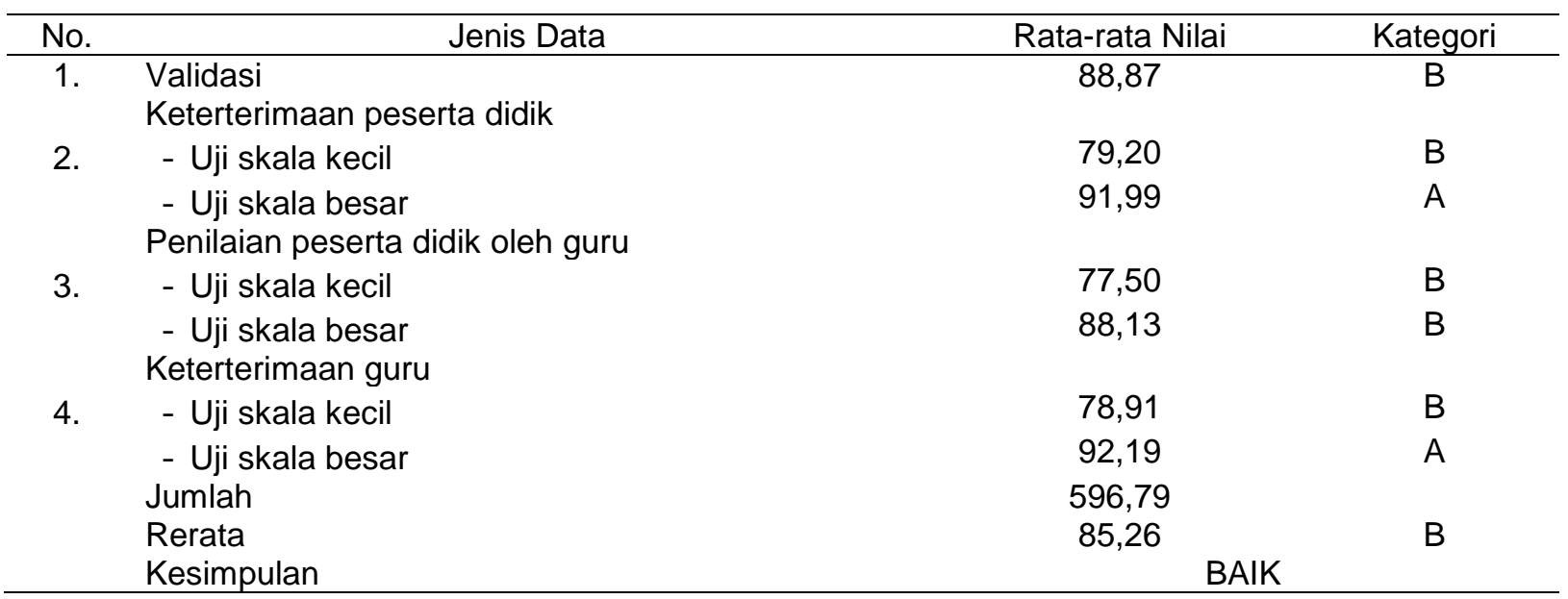

Hasil akhir yang diperoleh dari masing-masing instrumen yang dikembangkan dalam penelitian ini diperoleh nilai rata-rata 85,26 masuk ke dalam kategori BAIK, sehingga produk pengembangan model pembelajaran tematik materi penjasorkes yang dikembangkan peneliti dinyatakan layak untuk diterapkan dalam pembelajaran penjasorkes kelas II sekolah dasar.

Peserta didik dalam melakukan pembelajaran tematik sangat antusias, senang dan dapat mengeksplor kemampuan gerak, serta dapat belajar mata pelajaran yang lain, seperti yang ada dalam produk pengembangan yang dikembangkan. Dengan demikian produk pengembangan dari pembelajaran penjasorkes tematik yang dihasilkan membuat pembelajaran menjadi lebih menarik, menyenangkan, kontekstual dan menunjang pembelajaran mata pelajaran lain sesuai dengan tema yang ada.Peserta didik dalam melakukan pembelajaran tematik sangat antusias, senang dan dapat mengeksplor kemampuan gerak, serta dapat belajar mata pelajaran yang lain, seperti yang ada dalam produk pengembangan yang dikembangkan. Dengan demikian produk pengembangan dari pembelajaran penjasorkes tematik yang dihasilkan membuat pembelajaran menjadi lebih menarik, menyenangkan, kontekstual dan menunjang pembelajaran mata pelajaran lain sesuai dengan tema yang ada

Pelaksanaan uji coba berjalan dengan lancar dan menarik karena banyak siswa yang aktif dalam mengikuti pembelajaran tematik. Selain kuesioner yang diberikan siswa dan guru penjasorkes, keterlaksanaan pembelajaran tematik juga dinilai dalam produk pengembangan 


\section{Jurnal Pendidikan Jasmani Indonesia, 15 (1), 2019 - 27 \\ Maharani Fatima Gandasari}

ini. Hasil penilaian peserta didik pada proses pembalajaran yang meliputi kognitif, afektif dan psikomotor.

Hasil akhir yang diperoleh dari masing-masing instrumen yang dikembangkan dalam penelitian ini diperoleh nilai rata-rata 85,26 masuk ke dalam kategori BAIK, sehingga produk pengembangan model pembelajaran tematik materi penjasorkes yang dikembangkan peneliti dinyatakan layak untuk diterapkan dalam pembelajaran penjasorkes kelas II sekolah dasar.

\section{SIMPULAN}

Berdasarkan hasil penelitian dan pembahasan tentang pengembangan model pembelajaran tematik materi penjasorkes untuk sekolah dasar kelas II Kota Salatiga, maka dapat disimpulkan sebagai berikut: (1) Model pembelajaran tematik materi penjasorkes menjadi sebuah gambaran dan pedoman untuk guru penjasrokes dalam memahami tentang apa itu pembelajaran tematik, bagaimana pelaksanaan pembelajaran tematik, (2) Model pembelajaran tematik materi penjasorkes dapat meningkatkan kemampuan peserta didik pada aspek psikomotor, kognitif dan afektif berdasarkan hasil penelitian yang dilaksanakan di 22 sekolah dasar yang ada di Kota Salatiga, (3) Model pembelajaran tematik materi penjasorkes yang dikembangkan dapat menjadi lebih efektif, hal tersebut didapatkan hasil yang diperoleh dari respon positif peserta didik sebesar 85,59 (Baik) dan dari guru sebesar 85,55 (Baik), rata-rata 85,57 (Baik).

\section{DAFTAR PUSTAKA}

Frasandy, R. N. (2017). Integrative thematic learning (integration model of general subjects in (Islamic) elementary school with religious values). ELEMENTARY: Islamic Teacher Journal, 5(2), 303-355.

Hidayati, F. F. (2016). Pembelajaran pendidikan jasmani olahraga dan kesehatan kelas VDI MI Muhammadiyah Karanglewas Kidul Kecamatan Karanglewas Kabupaten Banyumas tahun pelajaran 2015/2016. Dissertation. IAIN Purwokerto

Husdarta, H. J. S. (2009). Manajemen pendidikan jasmani. Bandung: Alfabeta.

Prastowo, A. (2013). Pengembangan bahan ajar tematik panduan lengkap aplikatif. Yogyakarta: Diva Pres

Rustiana, E.R. (2013). Upaya peningkatan kecerdasan emosi siswa sekolah dasar melalui pendidikan jasmani harmoni. Jurnal Cakrawala Pendidikan, 5(1). doi:https://doi.org/10.21831/cp.v5i1.1267

Samsudin. (2008). Pembelajaran pendidikan jasmani olahraga dan kesehatan SD/MI. Jakarta: Litera.

Suhelli, S. (2018). Strategi guru dalam pencapaian tujuan pembelajaran tematik pada MIN di Kota Banda Aceh. PIONIR: Jurnal Pendidikan, 7(2).

Trianto, T. (2010). Mengembangkan model pembelajaran tematik. Jakarta: PT. Prestasi Pustakaraya 